\title{
Use of the mouse for the isolation and investigation of stomach-associated, spiral-helical shaped bacteria from man and other animals
}

\author{
ELIZABETH DICK, A. LEE, G. WATSON and JANI O'ROURKE
}

\section{School of Microbiology, University of New South Wales, PO Box 1, Kensington, Sydney, 2033 Australia}

\begin{abstract}
Summary. Spiral-helical shaped bacteria other than Campylobacter pylori have been shown to infect the human stomach. The characteristic helical morphology of these bacteria appears to be similar to that of bacteria found in the stomachs of many other animal species. Early reports on gastric bacteria suggested that rodents may be useful for investigation and isolation of stomach-associated bacteria. Therefore, anaesthetised mice were given, through a stomach tube, a heavy suspension of a spiral-helical bacterium from a cat, scrapings of gastric mucus from primates, or a homogenised whole-antral biopsy from a human patient. At intervals after inoculation, gastric biopsies were examined by lightmicroscopy and electronmicroscopy for the presence of spiral-helical bacteria. Significant colonisation was observed in $40 \%$ of mice 1 week, and in $80 \%$ of mice 11 weeks, after inoculation with suspensions of the cat isolate. Mice were also successfully colonised by spiral bacteria present in homogenised human biopsy material and by other spiral bacteria from a monkey. These observations suggest that mice may prove to be useful animals for the study of gastric bacteria that are, as yet, non-cultivable and for analysis of some of the attributes commonly thought to be involved in colonisation.
\end{abstract}

\section{Introduction}

Interest in bacteria of the stomach has increased following the implication of Campylobacter pylori in gastritis in man. More recently it has become apparent that bacteria other than $C$. pylori can infect the human stomach (Dent et al., 1987). These organisms have a very characteristic helical morphology on microscopy and appear similar to bacteria described in the stomachs of many animal species. It has been suggested that man may have acquired these helical bacteria from animal sources such as cats or dogs (Lee et al., 1988a). Thus, there is a need to isolate and investigate the association of these organisms with the stomach mucosa. None of these spiral-helical shaped bacteria has been cultured from human patients, although we have recently, and for the first time, cultured a spiral inhabitant of the cat stomach on laboratory media (Lee et al., 1988b).

Examination of the early reports on gastric

Received 4 Oct. 1988; accepted 29 Nov. 1988.

Requests for offprints should be sent to Ms Elizabeth Dick. bacteria suggested an approach which would facilitate not only the isolation of organisms from human patients but also allow the investigation of factors influencing colonisation of the stomach by bacteria. Salomon (1896) observed spirilla in the stomachs of cats and dogs, in the lumina of fundic glands, in the intracellular canaliculi of parietal cells and, at times, in the cytoplasm of these cells; he also successfully transmitted spiral bacteria from the gastric mucus of a dog, a cat and a Brown Norway rat to the fundic glands of white mice. Again, Kasai and Kobayashi (1919) demonstrated that "spirochaetes" from the stomachs of dogs could be transmitted to the gastric pits of mice, when mice were fed gastric mucus scrapings. Thereafter, Weber et al. (1958) used the mouse as a convenient method for maintaining the viability of these bacteria. If the early transmission experiments of these workers can be repeated, it seems likely that the rodent will provide a useful vehicle for the investigation of these bacteria. The work reported here suggests that the mouse has an important role in the study of stomach-associated bacteria, including the isolation of hitherto noncultivable organisms. 


\section{Materials and methods}

\section{Experimental animals}

Female mice, 6-8 weeks old, were obtained from an outbred colony maintained in the animal house of the School of Microbiology at the University of New South Wales, and were maintained on a diet of commercial food pellets (Rat and Mouse Kubes, Allied Feeds, NSW, Australia). Water was given ad libitum.

\section{Sources of spiral-helical shaped bacteria}

From a cat stomach. The culture was an isolate originally grown from the stomach of a normal adult cat as described elsewhere (Lee et al., 1988b). The organism was grown on Blood Agar Base No. 2 (Oxoid) with lysed horse blood (CSL, Parkville, Australia) $5 \% \mathrm{v} / \mathrm{v}$ and containing, L, amphotericin B (Fungizone, Squibb, Princetown, USA) $5 \mathrm{mg}$, trimethoprim (Sigma, St Louis, USA) $5 \mathrm{mg}$, polymyxin B (Sigma) 2500 IU and vancomycin (Eli Lilly, West Ryde, Australia) $10 \mathrm{mg}$. Plates were incubated, with lids uppermost, in a micro-aerophilic atmosphere (Oxoid) at $37^{\circ} \mathrm{C}$. The organism was stored in liquid nitrogen in Brain Heart Infusion Broth (Oxoid) containing glycerol $30 \% \mathrm{v} / \mathrm{v}$.

From a monkey stomach. These bacteria were obtained from the stomach of a Mandrill monkey (Papio sphinx) that had died of encephalomyelopathy at the Taronga Park Zoological Gardens, Sydney.

From a human stomach. Biopsies taken from the antrum and body of a patient with active-on-chronic gastritis were the sources of these non- $C$. pylori bacteria. They were associated with gastritis and had the characteristic morphology of spiral-helical shaped bacteria commonly seen in the stomachs of many animal species.

\section{Colonisation of mice by spiral bacteria from cat stomach}

Mice, that had been anaesthetised with ether, received a $0 \cdot 1-\mathrm{ml}$ inoculum of spiral bacteria (containing $10^{9}-10^{10}$ bacteria/ml) by stomach tube. Mice were killed by spinal dislocation 1 or 11 weeks after inoculation. A small piece of gastric tissue was placed with a sterile needle on a plate of lysed-blood agar, streaked for single colonies and incubated as above. Further pieces of tissue were removed for histology and electronmicroscopy.

\section{Colonisation of mice with spiral bacteria from other sources}

Scrapings of stomach mucus or, in the case of the human patient, the whole antral biopsy, containing motile spiral-helical bacteria, were homogenised in $2.0 \mathrm{ml}$ of saline with a Teflon grinder. Mice were anaesthetised with ether and $0.1 \mathrm{ml}$ of homogenate administered by stomach tube. The animals were killed up to 11 weeks after inoculation and stomach tissue was taken for culture, histology and electronmicroscopy as described below. Wet smears were examined by phase-contrast microscopy for the presence of motile bacteria.

\section{Microscopy}

Stomach tissue was fixed in either $10 \%$ formal bufferedsaline and embedded in paraffin for light microscopy, or in Karnovsky's fixative and embedded in Spurr's resin (Poly Sciences Inc., Warrington, USA) for electronmicroscopy (Karnovsky, 1965).

Paraffin sections $(5 \mathrm{~mm})$ were cut on a Spencer ' 820 ' microtome and stained with a modified Warthin-Starry silver stain, with the Brown and Hopps's stain, with a haematoxylin and eosin stain or with a May and Grunwald-Giemsa stain (Clark, 1973). The presence or absence of spiral-helical shaped bacteria was graded from $\mathrm{O}$ to +++ ; thus,,+++ and +++ indicated the presence of $1-5,6-15$ and $>15$ spiral-helical shaped bacteria/field of view, respectively; $O$ indicated the absence of these bacteria.

Semi-thin sections $(0.5 \mu \mathrm{m})$ and thin sections (50$70 \mathrm{~nm}$ ) were cut on a Reichart-Jung ultramicrotome. Semi-thin sections were stained with methylene blue (containing $1 \%$ borax) and examined by light microscopy. Thin sections were stained with uranyl acetate and lead citrate before examination with a Phillips 300 transmission electronmicroscope.

\section{Results}

\section{Colonisation of mice by spiral bacteria isolated from cat stomach}

Mice were consistently colonised by the characteristic spiral-helical bacterium from the cat. A light micrograph of a section of stomach from a mouse, killed 11 weeks after inoculation with spiralhelical bacteria from the cat, is shown (fig. 1). Large numbers of bacteria can be observed along the length of the gastric crypts and within the mucus which overlies the surface epithelium.

To grade the extent of colonisation in a number of mice, stained histological sections were coded, examined and graded (blind) by two independent members of our group and by an arbiter, before they were decoded. Significant colonisation was observed in $40 \%$ ( 8 of 20 ) of the mice killed 1 week after inoculation; however, 11 weeks after inoculation, heavy colonisation was observed in $80 \%$ (16 of 20) of mice. The bacteria were re-isolated from fresh gastric homogenates of these colonised mice. One of 20 control mice had small numbers of bacteria which were morphologically similar to a spiral-helical bacterium which colonises the ileum of rodents (Phillips and Lee, 1983).

When viewed by electronmicroscopy, the isolate from a cat stomach had very characteristic surface structures. The cell was entwined with a number of periplasmic fibrils that generally occurred in pairs. 

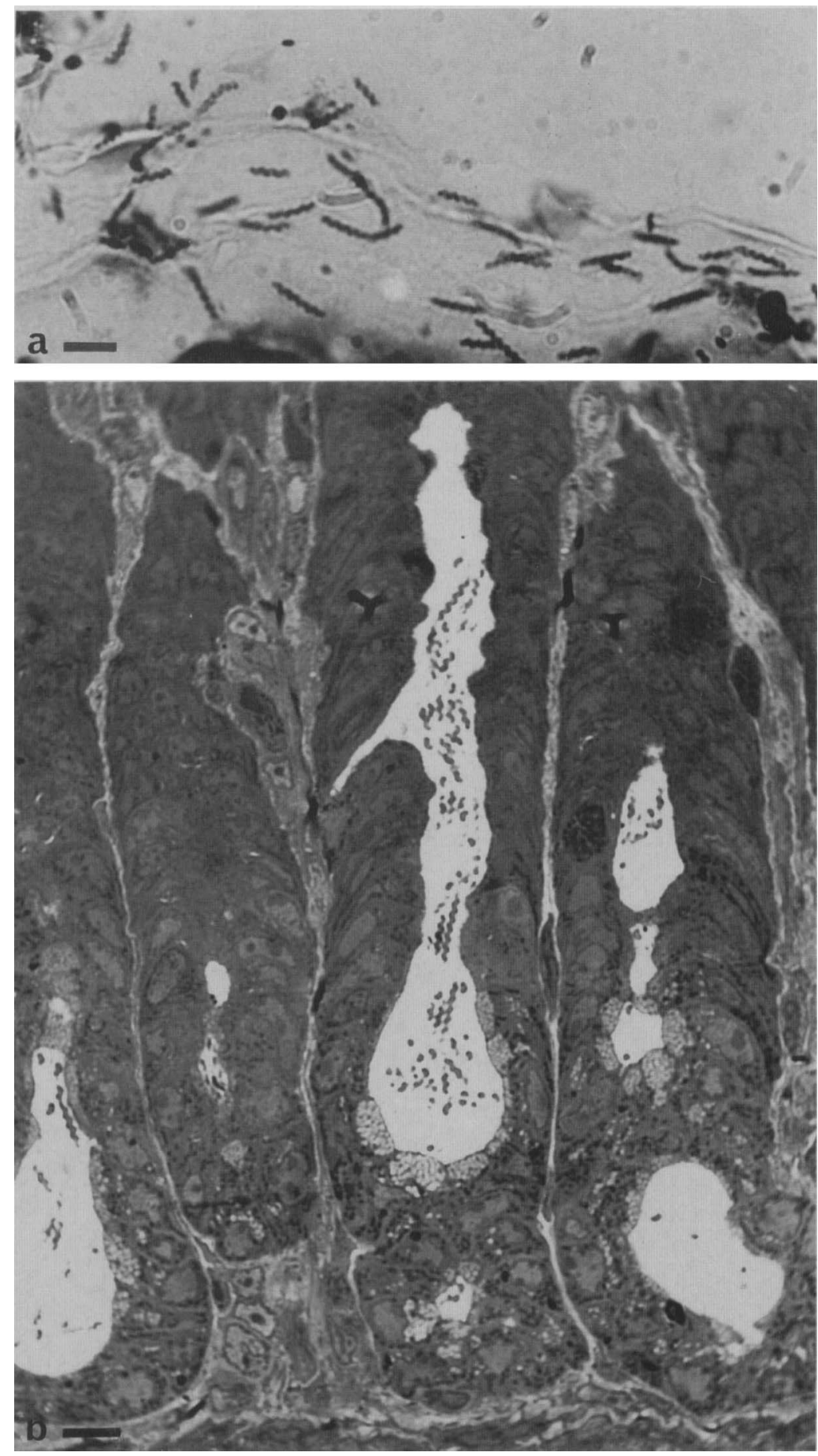

Fig. 1. Light micrograph of a section of mouse stomach 11 weeks after inoculation with spiral bacteria from a cat and showing numerous bacteria : (a) within the surface mucus layer; (b) within the gastric crypts. Bar $=4 \mu \mathrm{m}$. 
In cross-section, these fibrils were easily recognisable and, because bacteria with that kind of morphology have not been noted in the normal mouse gastrointestinal tract (Lee, 1985), it was possible to confirm that the organism colonising the gastric pits of the inoculated mice was the cat isolate. Bacteria with periplasmic fibrils were seen deep inside the gastric pits (fig. 2).

Colonisation of the mouse stomach by a non-C. pylori spiral bacterium from a human patient with active-onchronic gastritis

A 32-year-old Balinese man, who had lived in
Sydney for 2 years, presented with a 5-year history of epigastric discomfort. Histological investigation of gastric biopsies taken during a subsequent endoscopy revealed active-on-chronic gastritis associated with a bacterium with the tightly coiled spiral-helical morphology commonly observed in spiral bacteria from cats, dogs and primates.

Isolation was attempted at a repeat endoscopy but was unsuccessful. However, homogenates of the body and antral biopsies were inoculated into mice as described above. The appearance of the original human biopsy (fig. 3) and of sections from mice colonised with material from this patient (fig. 4) are shown. Attempts to isolate the organism from

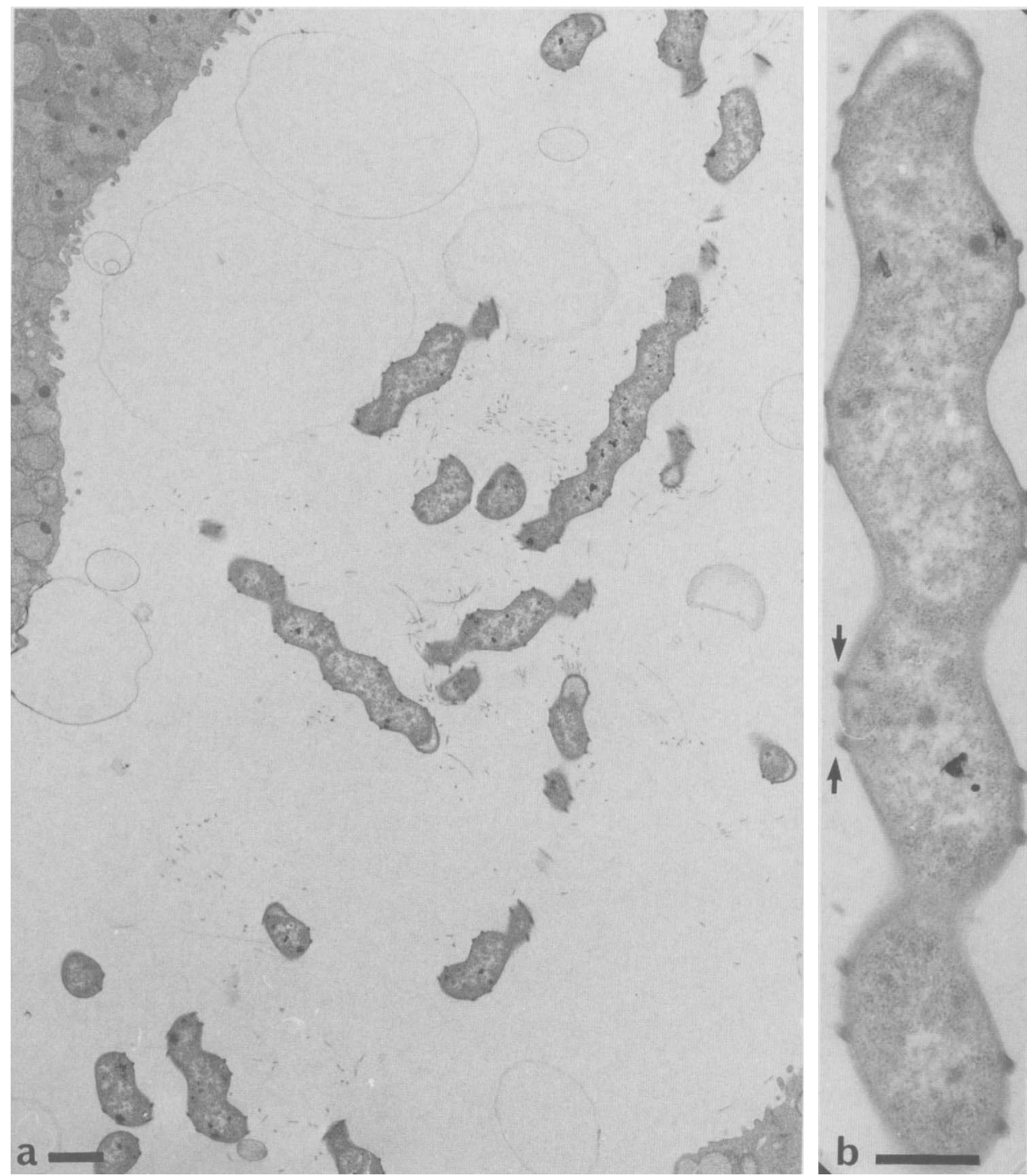

Fig. 2. Electronmicrographs showing, within a mouse gastric crypt, (a) spiral bacteria from a cat (bar $=0.5 \mu \mathrm{m})$ and $(\mathbf{b})$ the characteristic surface structures (arrows) (bar $=0 \cdot 25 \mu \mathrm{m})$. 


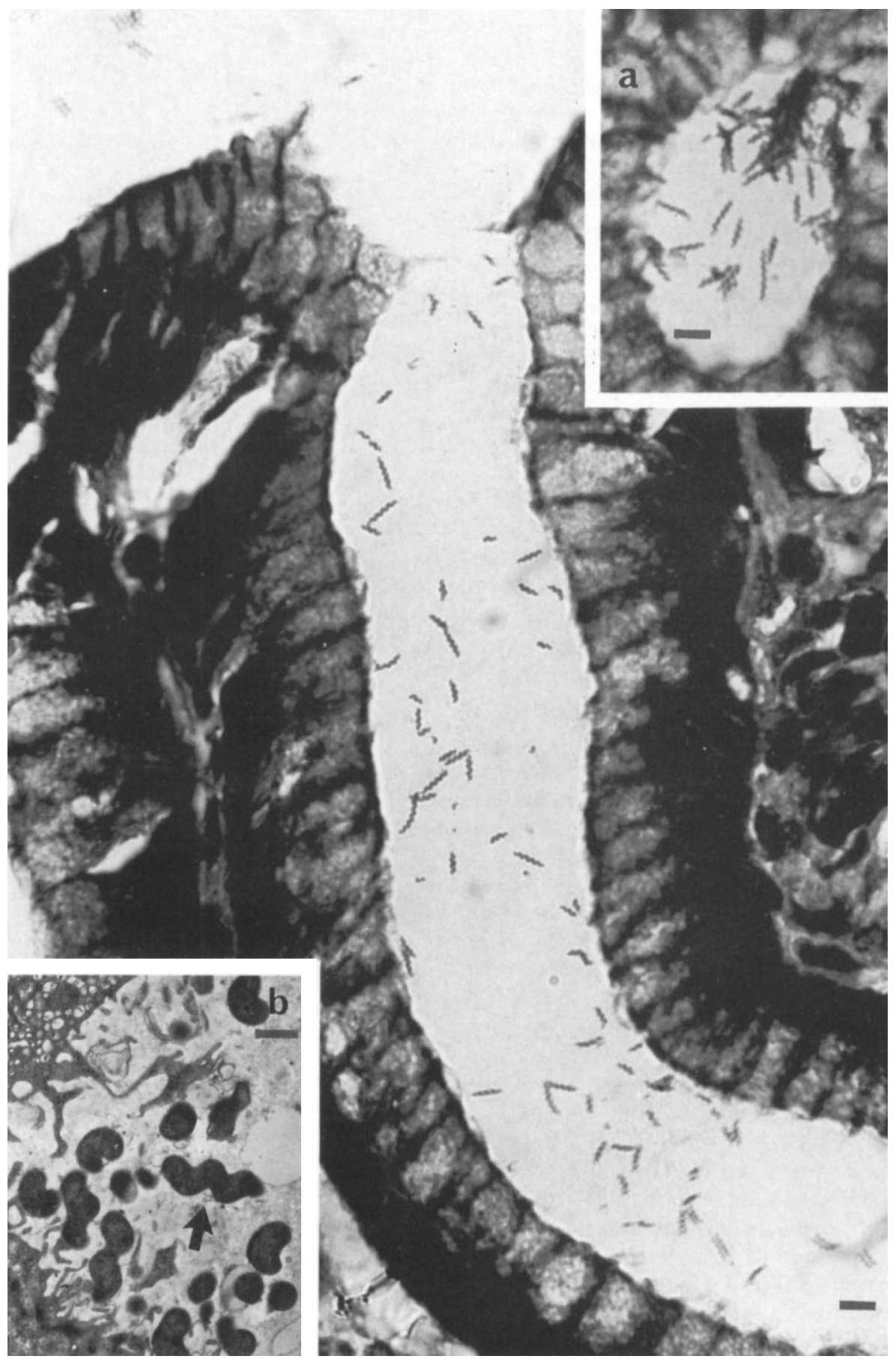

Fig. 3. Light micrograph of human gastric biopsy showing a longitudinal section through a crypt containing bacteria with a characteristic tightly coiled morphology ( $\mathrm{bar}=5 \mu \mathrm{m}$ ). Inset (a) shows a transverse section through a gastric crypt demonstrating the density of colonisation by spiral-helical bacteria (bar $=5 \mu \mathrm{m})$. Inset (b) is an electronmicrograph of bacteria closely associated with microvilli and shows the characteristic morphology (arrows) of these bacteria (bar $=1 \mu \mathrm{m}$ ). 
these mice have not been successful to date. However, the bacteria have remained viable in the mouse stomach for many weeks, as shown by their very rapid twisting motility when examined by phase-contrast microscopy. Successful transfer to other mice has also been achieved with homogenates of colonised-mouse stomach.

\section{Colonisation of the mouse stomach by spiral bacteria from a Mandrill monkey}

The death of a monkey at Taronga Park Zoo allowed us to determine if we could keep alive in the mouse organisms inhabiting the primate stomach. Mouse stomachs became heavily colonised after peroral inoculation of mucus preparation from the dead monkey. An electronmicrograph of these organisms in the mouse stomach is shown (fig. 5). Although the characteristic shape was clear the periplasmic fibrils generally observed on the cat isolate were not present on this organism suggesting that the latter belongs to a different species or genus.

\section{Discussion}

The early experiments of Salomon and Kasai suggested that colonisation of the stomachs of animals by indigenous spiral bacteria was not species specific (Salomon, 1896; Kasai and Kobayashi, 1919). These observations contrast with that of the human-associated spiral bacterium C. pylori, which has a very limited species range. Only germfree piglets and primates have been colonised with $C$. pylori, thus severely restricting the experimental investigation of factors that influence the association of this bacterium with gastric surfaces (Krakowka et al., 1987; Lambert et al., 1987; Newell et al., 1987). In the present report, colonisation studies with a pure culture of a spiral bacterium which naturally inhabits the cat stomach showed that the laboratory mouse, which does not normally have stomach-associated spiral organisms, can be heavily colonised by the cat isolate.

Given that $C$. pylori will not colonise the gastric mucosae of small animals such as mice, rats, rabbits and guinea-pigs (Krakowka et al., 1987), one way to gain an appreciation of factors influencing colonisation of the stomach surface and to explore distribution and effectiveness of antibacterial regimens is to study other spiral bacteria in an animal host. It has previously been suggested that the cat might afford such a model and, after the successful isolation of one of the cat bacteria, we have begun to use the cat for colonisation and therapeutic studies (Lee et al., 1988b). However, for work
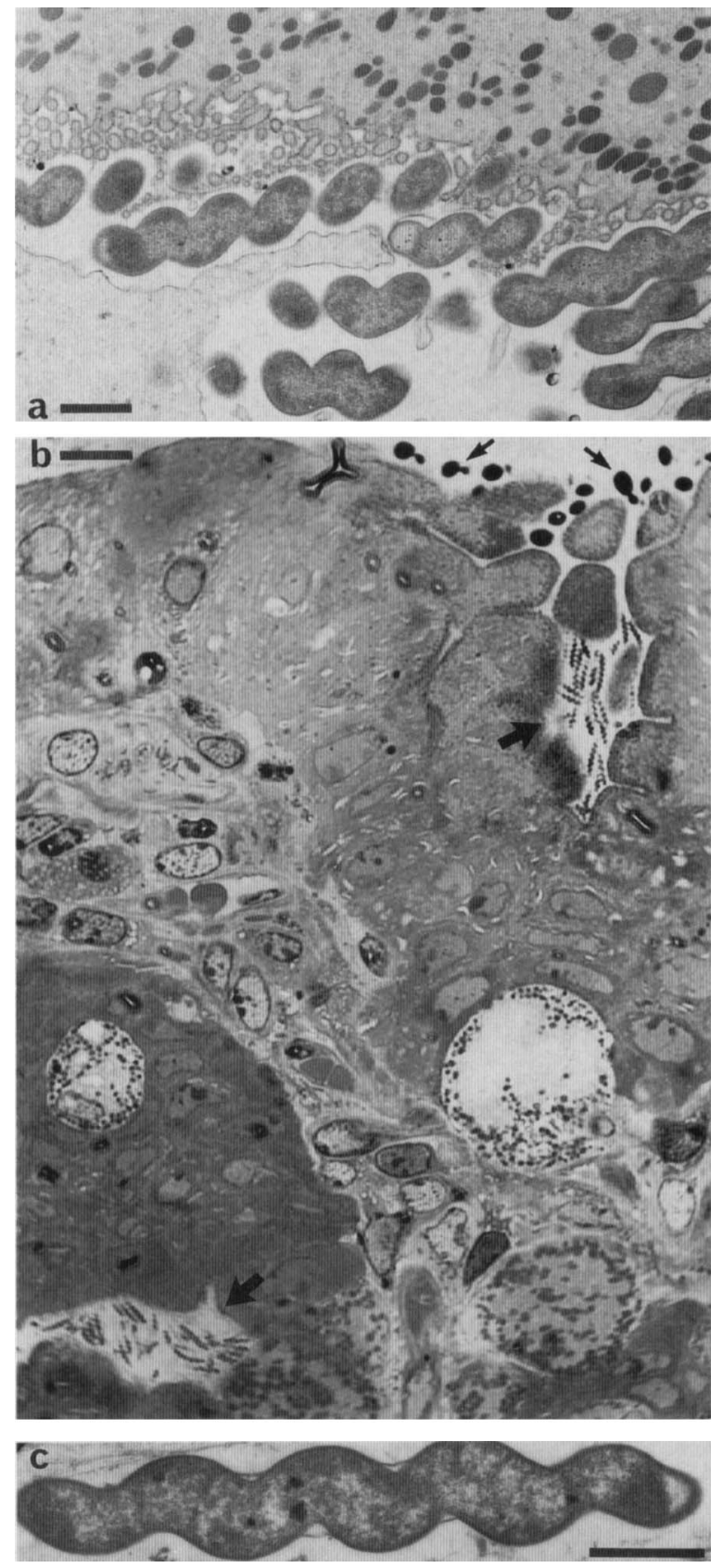

Fig. 4. Electronmicrograph of mouse gastric tissue colonised by spiral-helical bacteria from human gastric biopsies and showing the characteristic morphology of this group of bacteria within (a) the gastric crypts (bar $=1 \mu \mathrm{m})$ and (c) the surface mucus layer (bar $=0.40 \mu \mathrm{m}$ ). Light micrograph (b) demonstrates the heavy colonisation of the mouse gastric crypt with spiral-helical bacteria (large arrows) from man (bar $=2 \mu \mathrm{m}$ ). Note the presence of yeast cells which are part of the normal mouse gastric flora (small arrows). 


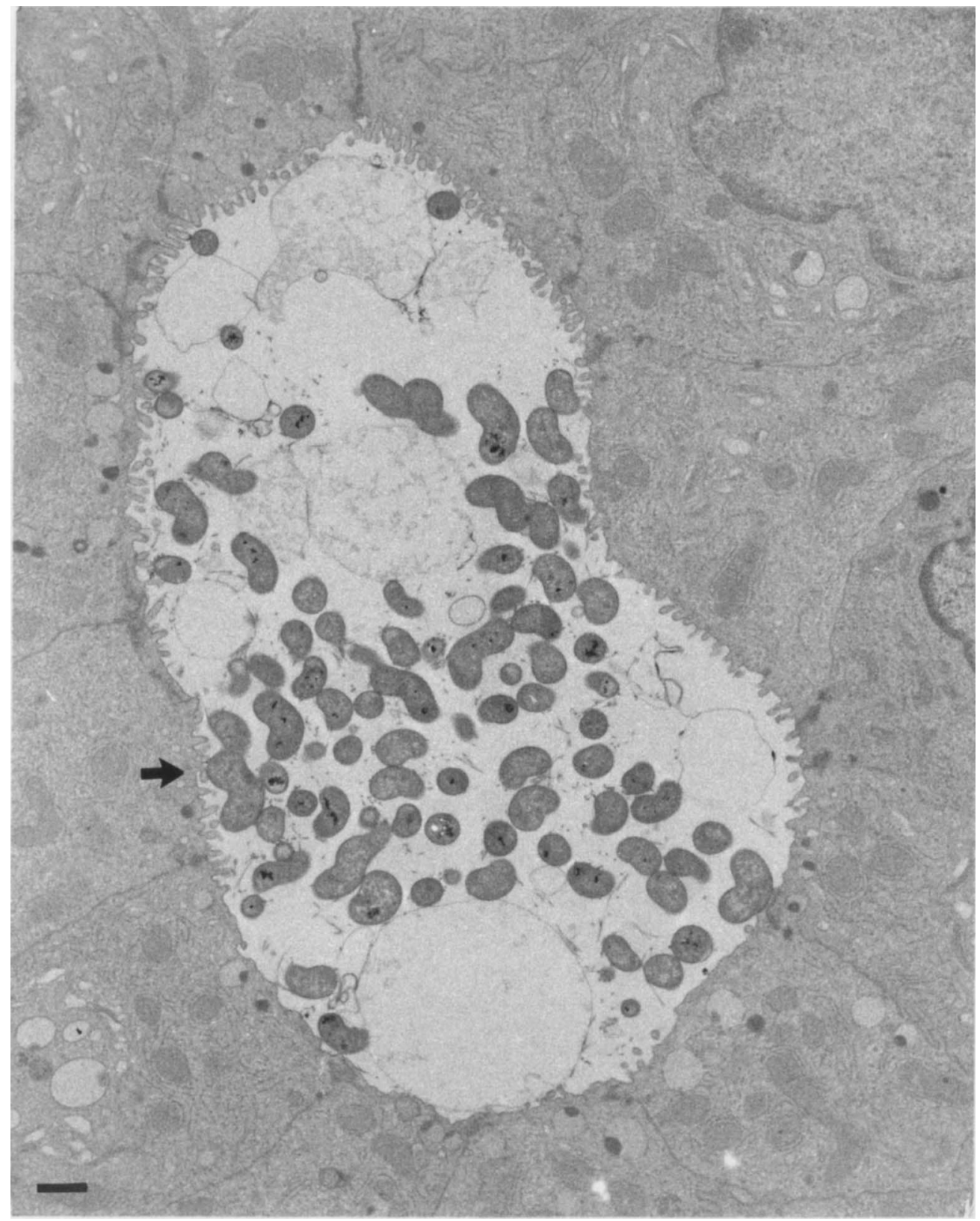

Fig. 5. Electronmicrograph of a mouse gastric crypt heavily colonised by spiral-helical bacteria from a Mandrill monkey and demonstrating the characteristic morphology of these bacteria. Bar $=1 \mu \mathrm{m}$.

requiring large numbers of animals, the use of cats is impractical. The mouse model described here appears to circumvent this problem. The mouse stomachs are heavily colonised in sites likely to be as inaccessble to chemotherapeutic agents as in the $C$. pylori-infected human stomach. The present findings on species-specificity indicate some differences in the factors likely to influence colonisation by $C$. pylori when compared with the cat isolate.
We are now, however, in a position to investigate the importance of common attributes that have been suggested previously to be involved in colonisation, i.e., micro-aerophilic conditions, specialised motility and possession of large amounts of urease enzyme (Langenberg et al., 1984; Hazell et al., 1986; Lee and Hazell, 1988).

The observation that the mouse stomach could be easily colonised by bacteria from the stomachs 
of other animals raised the possibility that the mouse might be a convenient vehicle for the study of bacteria which have not, as yet, been cultured. Past experience has shown that isolation of these previously non-cultivable mucus-associated bacteria is a long and laborious process, often requiring the use of many media, varied growth conditions and animals.

The use of the mouse to keep non-cultivable bacteria viable was shown in the studies with autopsy material from the Mandrill monkey and we have established a small colony of mice colonised by this organism. Isolation studies are in progress but at present the in-vitro culture of this particular spiral-helical bacterium has eluded us.

The importance of investigation of these nonC. pylori spiral- and helical-shaped bacteria has increased considerably since the demonstration of their presence in human patients. The more they are looked for, the more likely these organisms are to be found. In Sydney, for example, we found within 3 weeks of talking about these organisms to groups of gastroenterologists and histopathologists, two patients who were infected with these morphologically typical bacteria: one was a 2-year-old girl and the other a 32-year-old Balinese patient who had presented with non-ulcer dyspepsia. Clinical details of these cases will be published elsewhere. Our experience has suggested that the mouse might be of value in trying to isolate spiral

\section{REFERENCES}

Clark G 1973 Staining procedures used by the Biological Stain Commission, 3rd edn. Williams and Wilkins, Baltimore, pp 35, 36, 131 and 322 .

Dent J C, McNulty C A M, Uff J C, Wilkinson S P, Gear M W L 1987 Spiral organisms in the gastric antrum. Lancet 2: 96.

Hazell S L, Lee A, Brady L, Hennessy W 1986 Campylobacter pyloridis and gastritis: associated with intercellular spaces and adaptation to an environment of mucus as important factors in colonization of the gastric epithelium. Journal of Infectious Diseases 153: 658-663.

Karnovsky M S 1965 A formaldehyde-glutaraldehyde fixative at high osmolality for use in electron microscopy. Journal of Cell Biology 27: 137A-138B.

Kasai K, Kobayashi R 1919 The stomach spirochete occurring in mammals. Journal of Parasitology 6: 1-10.

Krakowka S, Morgan D R, Kraft W G, Leunk R D 1987 Establishment of gastric Campylobacter pylori infection in the neonatal gnotobiotic piglet. Infection and Immunity 55 : 2789-2\%96.

Lambert J R, Borromeo M, Pinkard K J, Turner H, Chapman C B, Smith M L 1987 Colonization of gnotobiotic piglets with Campylobacter pyloridis - an animal model? Journal of Infectious Diseases 155: 1344.

Langenberg M-L, Tytgat G N, Schipper M E I, Reitra P J G M, Zanen H C 1984 Campylobacter-like organisms in the stomach of patients and healthy individuals. Lancet 1 : 1348. bacterial from these patients. It was fortunate that the older patient was re-endoscoped as a participant in a treatment trial. Thus, whilst direct culture of biopsies failed, one biopsy fed to mice resulted in a colony of mice carrying the spiral bacterium in a vigorously motile, viable state. As can be seen from the photomicrographs, colonisation occurred in very large numbers. These animals provide us with an opportunity for some interesting investigations. Comparative histopathology between this bacterium in the mouse stomach and in man should provide important information relevant to our understanding of how $C$. pylori induces its pathological effect in man. We now have an opportunity to isolate this bacterium.

To date the bacterium isolated by us from the cat stomach is the only one of this morphological type to have been cultured in vitro. The studies above describe a simple, economic means of cultivation in vivo, in the rodent, of gastric bacteria from a wide range of animals, including man. This is an important step in our understanding of the properties of this group of stomach-associated microorganisms.

This work was supported by the National Health and Medical Research Council of Australia. The provision of specimens from the human patient by Drs J. Kellow and D. I. Fevre of the Royal North Shore Hospital, Sydney is gratefully acknowledged, together with the help of Dr R. Eckstein who performed the histopathology.

Lee A 1985 Neglected niches: the microbial ecology of the gastrointestinal tract. In: Marshall K C (ed) Advances in microbial ecology 8: 115-162.

Lee A, Dent J, Hazell S, McNulty C 1988 Origin of spiral organisms in human gastric antrum. Lancet 1 : 300-301.

Lee A, Hazell S L 1988a Campylobacter pylori in health and disease: an ecological perspective. Microbial Ecology in Health and Disease 1 : 1-16.

Lee A, Hazell S L, O'Rourke J, Kouprach S $1988 b$ Isolation of a spiral-shaped bacterium from the cat stomach: prelude to a better understanding of the factors that allow colonisation of the gastric mucosa in health and disease. Infection and Immunity 56: 2843-2850.

Newell D G, Hudson M J, Baskerville A 1987 Naturally occurring gastritis associated with Campylobacter pylori infection in the Rhesus monkey. Lancet 2: 1338.

Phillips M W, Lee A 1983 Isolation and characterization of a spiral bacterium from the crypts of the rodent gastrointestinal tracts. Applied and Environmental Microbiology 45: 675-683.

Salomon H 1896 Ueber das Spirillum des saugetiermagens und sein verhalten zu den belegzellen. Zentralblatt für Bakteriologie, Parasitenkunde und Infektionskrankheiten 19: 433-442.

Weber A F, Hasa O, Sutter J H 1958 Some observations concerning the presence of spirilla in the fundic glands of dogs and cats. American Journal of Veterinary Research 19: $677-680$. 